\title{
Cerebellar atrophy and muscle weakness: late-onset Tay-Sachs disease outside Jewish populations
}

\section{Katharina Marie Steiner, ${ }^{1}$ Johannes Brenck, ${ }^{1}$ Sophia Goericke, ${ }^{2}$ Dagmar Timmann ${ }^{1}$}

${ }^{1}$ Universitatsklinikum Essen Klinik fur Neurologie, Essen, Nordrhein-Westfalen, Germany ${ }^{2}$ Universitatsklinikum Essen Institut für Radiologie, Essen, Nordrhein-Westfalen, Germany

\section{Correspondence to} Dr Katharina Marie Steiner, katharinamarie.steiner@ukessen.de

Accepted 8 March 2016
CrossMark

To cite: Steiner $\mathrm{KM}$, Brenck J, Goericke $\mathrm{S}$, et al. BMJ Case Rep Published online: [please include Day Month Year] doi:10.1136/ bcr-2016-214634

\section{DESCRIPTION}

A 47-year-old Caucasian man of nonconsanguineous parents presented with a slowly progressive gait disorder and falls. Disease manifestations were present since early childhood with mild motor and mental retardation. Slowly progressive cerebellar ataxia, proximal muscle weakness and atrophy, mild cognitive decline and incomplete ophthalmoplaegia developed in late adolescence. At the time of presentation, he was still able to walk unaided for short distances. MRI of the brain (figure 1A, B) revealed marked cerebellar atrophy. The brainstem appeared unaltered. There were no white matter abnormalities. Nerve conduction studies were normal. Electromyography (EMG; figure 1C) and muscle biopsy revealed signs of chronic denervation reminiscent of lower motor neuron degeneration (or anterior horn disease). Neurological examination and magnetic motor test evoked potentials revealed accompanying pyramidal tract dysfunction. The $\beta$-hexosaminidase A activity was detectable, but significantly reduced $\left(0.02 \mathrm{E}_{405 \mathrm{~nm}} / 10^{6}\right.$ cells; normal activity $>0.3 \mathrm{E}_{405}$ $\mathrm{nm} / 10^{6}$ cells). Genetic testing revealed two known mutations in the $\beta$-hexosaminidase A (HEXA)-gene (c.805G >A; p.G269S and c.1274_1277dupTATC; p.Y427lfsX $\left.5,{ }^{1-2}\right)$, confirming the diagnosis of late onset Tay-Sachs disease (or GM2 gangliosidosis, variant B). Compound heterozygosity was verified by genetic testing of the neurologically healthy

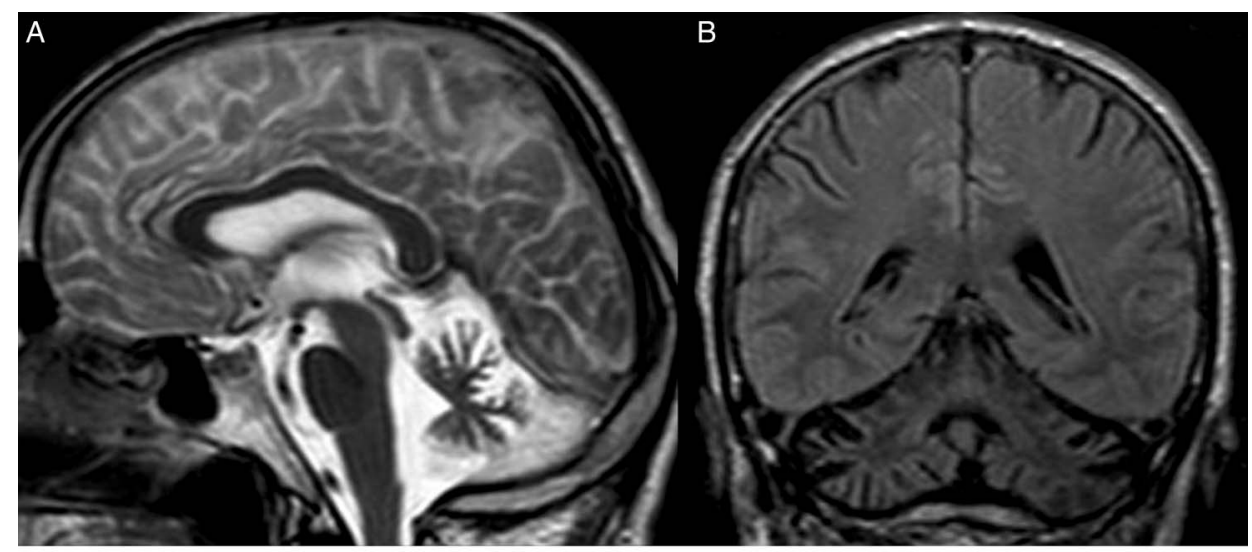

C

a

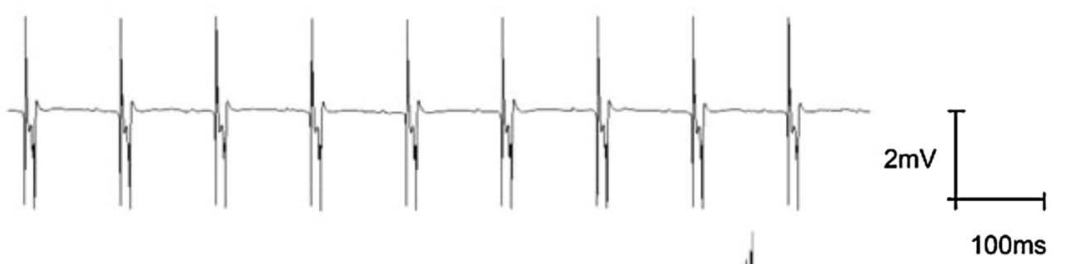

b

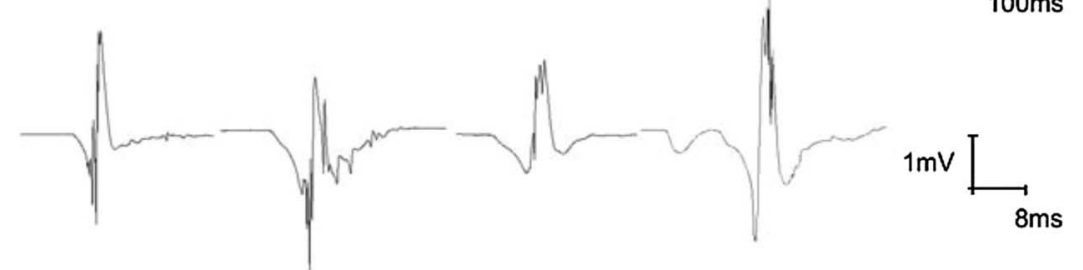

c

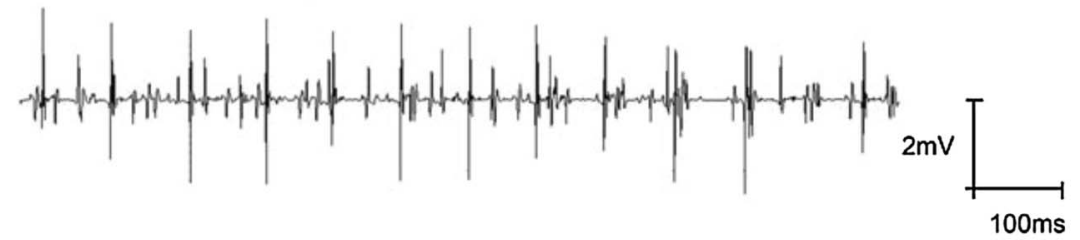

Figure 1 Cerebellar atrophy in (A) sagittal T2-weighted and (B) coronal fluid-attenuated inversion recovery (FLAIR) MRI of the brain; (C) Pseudomyotonic discharge (a), polyphasic muscle action potentials (b) and incomplete interference pattern during maximal contraction (c) in needle electromyography (EMG) recordings of the lateral vastus muscle. 
mother and sister, who carried one of the two mutations each. Late-onset Tay-Sachs disease/GM2 gangliosidosis is frequently accompanied by psychiatric disease, which was absent in the present case. ${ }^{3}$ In adults with cerebellar atrophy and signs of anterior horn disease, diagnostic considerations should include late-onset Tay-Sachs disease/GM2 gangliosidosis even in the absence of Ashkenazi Jewish ancestry and psychiatric disease.

\section{Learning points}

- In adults with cerebellar atrophy and signs of anterior horn disease, diagnostic considerations should include late-onset Tay-Sachs disease/GM2 gangliosidosis.

- Late-onset Tay-Sachs disease/GM2-gangliosidosis can occur without any considerable psychiatric symptoms and outside Jewish populations.

Acknowledgements The authors thank Professor Dr Ingeborg Krägeloh-Mann, Department of Paediatric Neurology, University Children's Hospital, Tübingen,
Germany, for analysis of the $\beta$-hexosaminidase activity; Dr Saskia Biskup, CeGaT $\mathrm{GmbH}$, Tübingen, Germany, for performing the genetic testing and commenting on the manuscript; and Dr Matthias Synofzik, Department of Neurodegenerative Diseases, Hertie-Institute for Clinical Brain Research, University of Tübingen, Germany, for helpful discussion of the case and commenting on the manuscript.

Contributors KMS was responsible for design and conceptualisation of the study and drafting the manuscript. JB and SG were involved in acquisition of data and revising the manuscript. DT was responsible for acquisition of data;

conceptualisation and supervision of the study; revising the manuscript.

Competing interests None declared.

\section{Patient consent Obtained.}

Provenance and peer review Not commissioned; externally peer reviewed.

\section{REFERENCES}

1 Myerowitz R, Costigan FC. The major defect in Ashkenazi Jews with Tay-Sachs disease is an insertion in the gene for the alpha-chain of beta-hexosaminidase. J Biol Chem 1988;263:18587-9.

2 Navon R, Proia RL. The mutations in Ashkenazi Jews with adult GM2 gangliosidosis, the adult form of Tay-Sachs disease. Science 1989;243:1471-4.

3 Neudorfer O, Pastores GM, Zeng BJ, et al. Late-onset Tay-Sachs disease: phenotypic characterization and genotypic correlations in 21 affected patients. Genet Med 2005; 7:119-23.

Copyright 2016 BMJ Publishing Group. All rights reserved. For permission to reuse any of this content visit http://group.bmj.com/group/rights-licensing/permissions.

BMJ Case Report Fellows may re-use this article for personal use and teaching without any further permission.

Become a Fellow of BMJ Case Reports today and you can:

- Submit as many cases as you like

- Enjoy fast sympathetic peer review and rapid publication of accepted articles

- Access all the published articles

- Re-use any of the published material for personal use and teaching without further permission

For information on Institutional Fellowships contact consortiasales@bmjgroup.com

Visit casereports.bmj.com for more articles like this and to become a Fellow 